\title{
Present and Future of Iron Ore in Japanese Iron Industry
}

\section{Kōsuke Kikuchi*}

\section{Councilor of The Iron and Steel Institute of Japan}

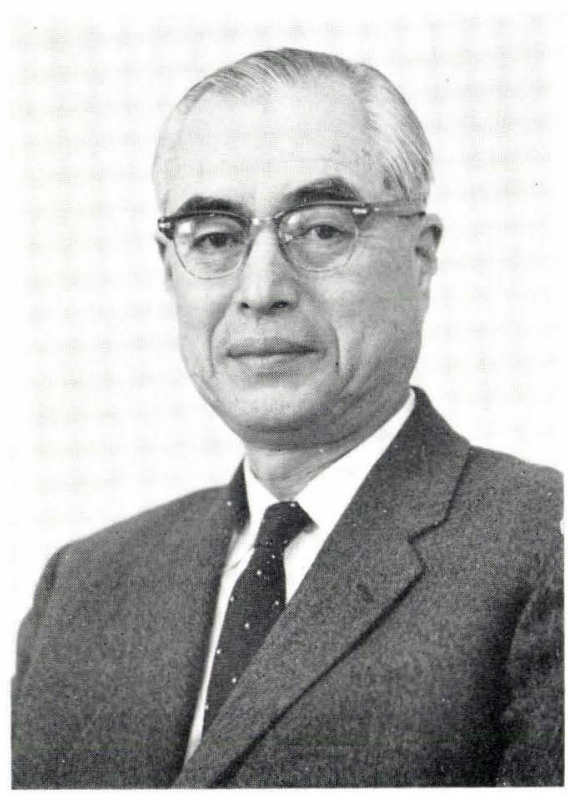

The Japanese iron and steel industry in the postwar years advanced by such wondrous leaps and bounds that its output of crude steel in fiscal 1963 has at last surpassed that of West Germany to assume 3rd place in the world, immediately following the U.S.A. and the U.S.S.R. Small wonder that other countries, surprised at the rapid progress made by Japan as an iron-making country despite her narrowly limited iron resources, revised their appraisal of the Japanese iron industry. In the production of pig iron to which that swift progress could be attributed, great contribution has been made not only by the improvement of pig making techniques but also by the upgrading of the iron ore and coke used; the development has been also due to the assurance of obtaining tremendous quantities of raw materials. How is the ore problem disposed of by Japan which has such inadequate resources of iron ore at home? We will review the current situation and then try to forecast the future. (It should be noted that the figures in the followings include some estimated ones.)

In 1963 Japan produced 31.5 mil. tons (34.1 mil. tons for fiscal 1963) of crude steel, or a $14 \%$ increase over the preceding year, using 34.5 mil. tons of iron ore, of which 27 mil. tons came from overseas, marking a 17\% increase over the preceding year's importation. The increase is striking in comparison with the figure of 1950 when the importation of ore was 1.5 mil. tons. The domestic production of ore was 7.50 mil. tons which accounted for no more than $22 \%$ of the total requirement of ore, the breakdown of which being: pyrite cinder $23 \%$, black sand $17 \%$, iron ore $15 \%$ and other materials $45 \%$. As the last item represents mostly such iron sources as slag, dust, mill scale, etc. which were produced at iron mills, iron ore supplied from the mines amounted to $55 \%$ ( 4.1 mil. tons). Most of the iron ore is of low grade, and pyrite cinder and black sand are fines which do not qualify as good raw materials of iron-making. Thus, Japan relies on importation for about $80 \%$ of the total iron ore supply. The countries of origin extend from Asian territories to South America and Africa. When ore is transported long distances, it does not pay unless it is of high grade, for the transportation charges rise in proportion to the mileage covered. Therefore, the grade of ore imported from South America is in the order of $\mathrm{Fe} 65 \%$, and the average $\mathrm{Fe}$ of imported ores of late is about $62 \%$. On the other hand, the average $\mathrm{Fe}$ of indigenous ore being $53 \%$, the overall average of Fe of iron ores used in Japan comes to about $60 \%$. This Fe grade is the highest of all ores fed to blast furnaces throughout the world.

As Japan is poor in iron ore and iron-making coal resources, most of the iron mills are built along the seashore so as to facilitate the importation of these raw materials and are equipped with harbor of large scale. These days, in an effort to economize on transportation expenses, giant ore carriers have begun to be used to import quantities of iron-making raw materials, with the result that the route of ore transportation is not seriously affected by the shift of ore producing countries.

Of Japan's importation of iron ore in 1963, the major supplying countries and their respective percentages to the total are as follows. The figures in the brackets show the percentages of respective supplying countries to the total importation of 14.86 mil. tons of ore in 1960 .

$\begin{array}{lrlll}\text { 1. Malaya } & 25.8 \%(36) & \text { 2. } & \text { South America } & 25.5 \%(8) \\ \text { 3. Goa } & 10.8 \%(13) & \text { 4. } & \text { India } & 7.3 \%(16) \\ \text { 5. Canada } & 7.0 \%(7) & 6 \text {. U.S.A. } & 7.0 \%(6) \\ \text { 7. The Philippines } & 5.4 \%(8) & \text { 8. Others } & 11.2 \%(6)\end{array}$

* Dr. Eng., Executive Managing Director, Kokan Mining Co., Ltd. 
During the 4 years from 1960 to 1963 the importation of ore increased by 11 mil. tons, and remarkable changes were seen in the supplying countries. Dividing the supplying countries of imported ore into Asian areas and American areas for the purpose of comparison, we note that in 1960 the Asian areas accounted for $73 \%$ and the American areas, 21\%, whereas in 1963 these figures changed to 54\% and 42\% respectively. The increase in the American areas was chiefly due to the increase of ore from Peru and Chile. From this it is clear that Japan, as it produces more iron and steel, looks for sources of supply of ore in increasingly remote parts of the globe.

The outlook for the future demand of iron and steel may differ depending upon what policy is taken. For the present the goal for the production of crude steel in Japan is set at 48 mil. tons to be achieved by 1970. To achieve this goal, blast furnace pig production in the vicinity of 33.5 mil. tons, will be necessary annually and the demand for iron ore will amount to 56 mil. tons. Supposing that, of this total demand of ore, about $12 \mathrm{mil}$. tons is provided at home, 44 mil. tons of foreign ore will have to be purchased, which means 1.6 times the tonnage for 1963. The question will be where to find the sources of the mounting tonnage of imported ore. In Australia, of late, plans for supplying iron ore to Japan are being worked out on a gigantic scale. Australia had prohibited the export of iron ore; however, since the ban was removed recently, plans for development have been made public one after another. A few Australian firms are already sounding out the marketing possibilities of ore in Japan. One of them has ore reserves of no less than several hundreds of millions of tons to be extracted at a rate of 5 mil. tons a year. In view of the fact that the distance to that country is shorter than to South America, Australia will in the future be a great supplier of iron ore to Japan. India also has mines of great magnitude which are under development with Japanese co-operation and promise a bright future. Besides, the resources of South America and Goa are rich and increases in exports may be expected from these lands. From such a view point the future importation of iron ore into Japan will fully meet her requirements, having as major sources South America, India, Goa and Australia.

Furthermore, in Japan, the progress in the techniques of blast furnace operations has aroused an eager attention as to the quality of ore. As a consequence such preliminary treatments of ore as the blending of ores to reduce the differences between their types, the sizing of lump ore, the sintering or pelletizing of fine ore, etc. are being applied in good earnest. These treatments have brought about a remarkable improvement in the efficiency of blast furnaces. Sintered ore now under production is almost self-fusing. In 1963 it was used in the blast furnace at a rate of as high as 63\%.

Of late, in the U.S.A., taconite ore of low grade is being processed into pellets with equipment of a capacity amounting to more than 40 mil. tons, and nearly one half of the ore used there will be supplied from this source in the course of time, thanks to the higher esteem of pellets because of their higher grade as well as better reaction. In Japan, too, 3 mills are making pellets, all operating within the compounds of their iron mills, and using as principal raw materials either black sand and pyrite cinder or general fine ore. Enthusiasm for the use of pellets has mounted in Japan since last year, and various experiments have been conducted with a view to commercial operations, resulting in an expectation that the importation of pellets from North and South America, Goa, etc. will be realized shortly.

Scant iron resources in Japan have hampered her active research into iron ore. Nevertheless, the abundance of laterite in Asian countries induced Japanese iron mills in the postwar years to divert their research toward that ore. This research has been conducted for two years in the institution of the Laterite Research Division within the Joint Research Society of The Iron and Steel Institute of Japan, and thanks to earnest investigations on a well co-ordinated plan, a stage has been reached recently where tests would be carried out with small scale industrial equipment.

As mentioned above, Japan can at present take advantage of the buyer's market in obtaining the ore of desired quality, and pig making efficiency has risen remarkably. However, as the production of iron and steel increases in each country henceforth, the time will come when it will be difficult to get hold of high grade ore. Although various measures are being taken by Japan for the securing of iron resources in the near future, a stage has been reached where the processing of the poor and fine ore deposited in neighboring countries should also be seriously studied for the future. Little difficulty, however, is seen on the way to immediate procurement of ore to meet the requirements of increasing iron and steel production in Japan. 